\title{
Reasons for Student Enrollment in Nursing Studies
}

1 Snježana Čukljek

1 Janko Babić

1 Ana Marija Hošnjak

1 Sanja Ledinski Fičko

1 Martina Smrekar

1 University of Applied Health Sciences, Zagreb, Croatia

Article received: 01.09.2020.

Article accepted: 03.11.2020.

https://doi.org/10.24141/2/4/2/4

Author for correspondence:

Snježana Čukljek

University of Applied Health Sciences

Mlinarska 38, Zagreb, Croatia

E-mail: snjezana.cukljek@zvu.hr

Keywords: nursing, education, reasons for enrolment

\section{Abstract}

The aim of the research was to determine the reasons for students enrolling in nursing studies, priorities in the choice of studies and differences in the reasons and priorities for choosing enrollment with regard to previously completed high school. The research was conducted on full-time nursing students of the University of Applied Health Sciences who enrolled in the first year of study in the academic year 2017/2018 and 2018/2019. For the purpose of the research, an anonymous questionnaire was used. The questionnaire includes questions related to demographic data and questions about the reasons related to enrollment in nursing studies, whether any of their family members or friends work in the health care system and whether any of the members of their family is a health worker. Students were required to rank their choice of the study of nursing on a scale of 1 to 10 at the time of enrollment. Students who have previously completed high school for nurses most often stated the expansion of existing knowledge, the acquisition of new knowledge, and the continuation of previous education as the reasons for enrolling in nursing studies. Students who have completed other types of high schools stated interest in medicine, nursing, health, helping others, good employment opportunities, and nursing being interesting as reasons for enrollment. Participants in this research significantly more often stated that their family members do not work in the health care system. When enrolling in the study, the majority of the students' first choice was the study of nursing at the higher education institution where the research was conducted - in the $201774.7 \%$ of participants, and in $201867.3 \%$ of participants. There is no statistically significant difference in the average ranking of the choice of the nursing study with respect to the year of enrollment $(p=0.692)$. Information on the reasons for enrollment can help in planning the promotion of studies and nursing profession in public to encourage students to enroll. 


\section{Introduction}

Today, nursing care is provided by 27.9 million nurses worldwide. Although there is an increase in the number of nurses, the World Health Organization reports a shortage of 5.9 million nurses (1). The lack of nurses is also observed in the health care system of the Republic of Croatia - in the EU countries there are on average 8.4 nurses per 1000 inhabitants, while in Croatia the ratio is lower and amounts to 6.3 nurses per 1000 inhabitants (2).

One of the basic ways to increase the number of nurses is to educate more pupils and students and that they stay in the profession. It is important to carefully select students, encourage their enrollment in nursing education programmes, know the reasons for enrollment so that, if necessary, they can be modified during the educational process. Knowing the reasons for enrollment can contribute to increasing the number of enrolled students if they are pointed out when promoting studies and the profession in public, that is, data can be obtained that may indicate the need to change how nursing profession is presented in public.

Educating nurses is demanding, expensive and time consuming therefore it is important to prepare students for professional nursing practice and for staying in the profession. Research shows that more than $20 \%$ and up to $40 \%$ of students drop out of their studies (3-6). Research shows that students enroll in nursing studies for altruistic reasons such as the desire to provide care for the sick and infirm (7-14), economic reasons such as job security (9-11, 13-16), and their previous experience with nurses and the health environment $(9,17)$. As a significant factor for enrollment, students state the value of the nursing profession in the community $(10)$ and the diversity of work environments $(9,11,15,16)$. Important for the choice of profession are the role models in the family, among friends, the influence of the family as well as positive experience with nurses $(9,11,15-18)$. Positive previous experience in caring for the sick, and insufficient knowledge of the nursing profession often cause an idealistic perception of nursing, which can cause stress and discomfort during studies due to the discrepancy between the ideal picture of nursing and nursing as it really is $(17,19)$. The initial realistic view of nursing is associated with successful completion of studies and remaining in the health sector $(15,20)$.

The study of nursing in the Republic of Croatia is enrolled by students with previously completed high school education. Traditionally, a large number of students after graduating from high school for nurses continue their education in the study of nursing and they make up the majority of the students. In recent years, the number of students enrolling in nursing studies after completing other types of high schools has increased, with the largest number of them previously graduating from gymnasiums.

The aim of the research was to determine the reasons for enrollment in the study of nursing, priorities in the choice of studies and differences in the reasons and priorities for choosing to enroll in relation to previously completed high school. We also wanted to find out whether any of the family members or friends works in the health care system, i.e. whether any of the family members is a health worker, and whether there are differences between the two generations of students.

\section{Methods}

\section{Study design}

A cross-sectional survey was conducted.

\section{Participants}

The research was conducted on full-time nursing students of the University of Applied Health Sciences who enrolled in the first year of study in the academic years 2017/2018 and 2018/2019.

In October 2017, 103 participants completed the questionnaire. The majority of $\mathrm{N}=93$ participants were female (90.3\%). The age range was between 18 and 23 years, $M=19.53$. The majority of participants 87.09\% $(\mathrm{N}=81)$ completed high school for nurses. Other participants graduated from other types of high schools, most often gymnasiums.

In October 2018, 107 participants completed the questionnaire. The majority of participants were fe- 
male 96 participants (89.7\%). The age ranged from 18 to 31 years, $M=19.65$. The majority of participants $57.9 \%(\mathrm{~N}=62)$ completed high school for nurses. Other participants completed other types of high schools, most often gymnasiums 31\% ( $N=34)$.

\section{Data collection}

Students voluntarily completed an anonymous questionnaire, developed for the purposes of this research, which includes questions related to demographic data (age, gender, high school education) and questions related to reasons for enrollment in nursing studies. When completing the questionnaire, students were asked to state three reasons why they enrolled in nursing studies (open-ended question where they could state from one to three reasons). It was also necessary to state whether any of their family members or friends work in the health care system and whether any of their family members is a health care worker. Students were required to rank their choice of the study of nursing on a scale of 1 to 10 at the time of enrollment in higher education. A written copy of the questionnaire was distributed to students during a lecture in the field of nursing care, and filling of the questionnaire lasted about 10 minutes.

\section{Ethics}

The Ethics Committee of the educational institution in which the research was conducted approved the conduction of the research (Class: 602-04/1718/588, Reg. No. 251-379-1-17-02). Participants were given an oral explanation of the purpose of the survey, and they also received a written notice for the participants where the purpose of the survey was explained. Students participated in the research voluntarily and anonymously.

\section{Results}

The answers of the students related to the reasons for enrollment in the study were entered in a table and analyzed according to the content of the answers. They were categorized according to the simi- larity of the answers and the answers of students who previously graduated from high school for nurses were compared with the answers of the students who previously graduated from other types of high schools.

Table 1. Overview of all answers of students who enrolled in the first year of study in 2017.

All answers

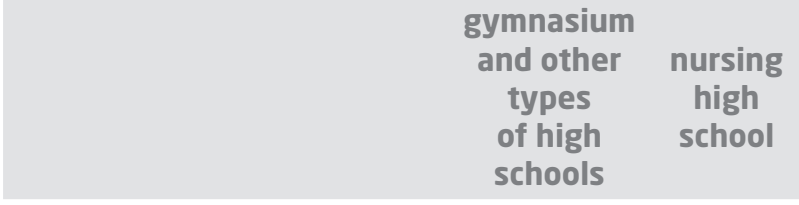

continuing previous education in the profession

22

desire to study (student role)

6

6

status - title, working with doctors

loves the job of a nurse 1 13 expanding existing knowledge

broader competences

0

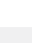

reater (good) employment opportunity

\begin{tabular}{cc}
0 & 32 \\
0 & 42 \\
0 & 4 \\
13 & 12 \\
\hline
\end{tabular}

\begin{tabular}{|c|c|c|}
\hline working with people & 3 & 5 \\
\hline likes to help & 8 & 14 \\
\hline higher salary & 1 & 7 \\
\hline advancement in profession & 0 & 11 \\
\hline better working conditions & 0 & 6 \\
\hline wants to be a nurse & 2 & 0 \\
\hline interesting and dynamic work & 7 & 7 \\
\hline $\begin{array}{l}\text { interest in medicine/nursing, } \\
\text { health }\end{array}$ & 17 & 3 \\
\hline humanity & 3 & 1 \\
\hline new experiences & 0 & 5 \\
\hline other & 1 & 5 \\
\hline Total & 62 & 195 \\
\hline
\end{tabular}

In a survey conducted in 2017, students who previously graduated from a nursing high school most often stated the following as reasons for enrolling in nursing studies: expanding existing knowledge (42 participants), loving the job of a nurse (32 participants) and continuing previous education (22 participants). Among students who had previously com- 
pleted other types of high schools, the most common reasons were interest in medicine, nursing, health (17 participants) and good employment opportunities (13 participants).

\begin{tabular}{|ccc|}
\hline $\begin{array}{c}\text { Table 2. Overview of the answers of students } \\
\text { who enrolled in the first year of study in } \mathbf{2 0 1 7} \\
\text { listed as their first reason for enrollment } \\
\text { gymnasium } \\
\text { and other } \\
\text { types } \\
\text { of high } \\
\text { schools }\end{array}$ & $\begin{array}{c}\text { nursing } \\
\text { high } \\
\text { school }\end{array}$ \\
$\begin{array}{c}\text { continuing previous education } \\
\text { in the profession }\end{array}$ & 0 & 18 \\
\hline desire to study (student role) & 4 & 4 \\
\hline $\begin{array}{c}\text { status - title, working with } \\
\text { doctors }\end{array}$ & 0 & 7 \\
\hline greater (good) employment & 4 & 0 \\
opportunity & 0 & 6 \\
\hline likes to help & 0 & 2 \\
\hline working with people & 0 & 1 \\
\hline job security & 0 & 1 \\
\hline higher salary & 0 & 4 \\
\hline advancement in profession & 1 & 0 \\
\hline wants to be a nurse & 3 & 1 \\
\hline interesting and dynamic work & 7 & 0 \\
\hline interest in medicine/nursing, \\
health
\end{tabular}

When the reasons given in the first place are analyzed, the results are very similar to the overall results. Students who had previously completed a high school for nurses stated the following as the most important reasons for enrolling in nursing studies: the expansion of existing knowledge (18 participants) and the continuation of previous education (18 participants). Students who had previously completed other types of high schools most often indicated an interest in medicine, nursing and health care as most important reasons (7 participants).
Table 3. Overview of all answers of students

who enrolled in the first year of study 2018.

All answers

\begin{tabular}{|c|c|c|}
\hline & $\begin{array}{c}\text { gymnasium } \\
\text { and other } \\
\text { types } \\
\text { of high } \\
\text { schools }\end{array}$ & $\begin{array}{c}\text { nursing } \\
\text { high } \\
\text { school }\end{array}$ \\
\hline desire to study (student role) & 4 & 15 \\
\hline job security & 14 & 15 \\
\hline helping other people & 24 & 8 \\
\hline interesting & 16 & 6 \\
\hline interest in medicine/nursing & 10 & 0 \\
\hline working with people & 13 & 0 \\
\hline wants to be a nurse & 5 & 0 \\
\hline humane & 2 & 1 \\
\hline good occupation & 5 & 0 \\
\hline $\begin{array}{l}\text { continuing previous education } \\
\text { in the profession }\end{array}$ & 0 & 28 \\
\hline acquiring new knowledge & 0 & 22 \\
\hline $\begin{array}{l}\text { higher salary, better work } \\
\text { conditions }\end{array}$ & 0 & 11 \\
\hline likes to be a nurse & 0 & 17 \\
\hline $\begin{array}{l}\text { expanding existing } \\
\text { knowledge }\end{array}$ & 0 & 8 \\
\hline other & 4 & 10 \\
\hline Total & 97 & 141 \\
\hline
\end{tabular}

In a survey conducted in 2018, students who had previously completed a high school for nurses as reasons for enrolling in nursing studies most often stated the following: continuing previous education (28 participants) and acquiring new knowledge (22 participants). For students who had previously completed other type of high school education, the most common reasons were helping others (24 participants) and that nursing is interesting to them (16 participants).

When the reasons stated as first are analyzed, the results are very similar to the overall results. Students who had previously completed a high school for nurses as the primary reasons for enrollment in the study of nursing most often stated the continuation of previous education (23 participants). Students who had previously completed other types of high school as their primary reason stated that nursing was interesting to them. 


\begin{tabular}{|c|c|c|}
\hline & $\begin{array}{l}\text { gymnasium } \\
\text { and other } \\
\text { types } \\
\text { of high } \\
\text { schools }\end{array}$ & $\begin{array}{l}\text { nursing } \\
\text { high } \\
\text { school }\end{array}$ \\
\hline desire to study (student role) & 3 & 9 \\
\hline job security & 5 & 2 \\
\hline helping other people & 5 & 2 \\
\hline interesting & 9 & 3 \\
\hline interest in medicine/nursing & 5 & 0 \\
\hline working with people & 6 & 0 \\
\hline wants to be a nurse & 5 & 0 \\
\hline $\begin{array}{l}\text { continuing previous education } \\
\text { in the profession }\end{array}$ & 0 & 23 \\
\hline acquiring new knowledge & 0 & 6 \\
\hline $\begin{array}{l}\text { higher salary, better work } \\
\text { conditions }\end{array}$ & 0 & 1 \\
\hline status & 0 & 1 \\
\hline likes to be a nurse & 0 & 9 \\
\hline advancement in profession & 0 & 3 \\
\hline other & 1 & 1 \\
\hline Total & 39 & 60 \\
\hline
\end{tabular}

When analyzing the answers to the questions on ranking nursing studies at enrollment, the Mann Whitney $U$ test was applied because the Kolmogorov-Smirnov test of normality of the distribution of ranking found that the distribution of results differs significantly from the normal distribution $(p=0.000)$.

When enrolling in the study, most students in the first place mentioned the study of nursing at the higher education institution where the research was conducted. In the 2017 sample, the study of nursing was the first choice for 77 (74.7\%) participants, and in 2018 for 72 (67.3\%) participants. The study of nursing was the first or second choice for more than $80 \%$ of participants $(89.3 \%$ and $82.2 \%$ of participants, respectively).

There is no statistically significant difference in the average ranking of the choice of nursing study with respect to the year of enrollment (2017 or 2018) $M-W U=5278.500 ; p=0.692$.

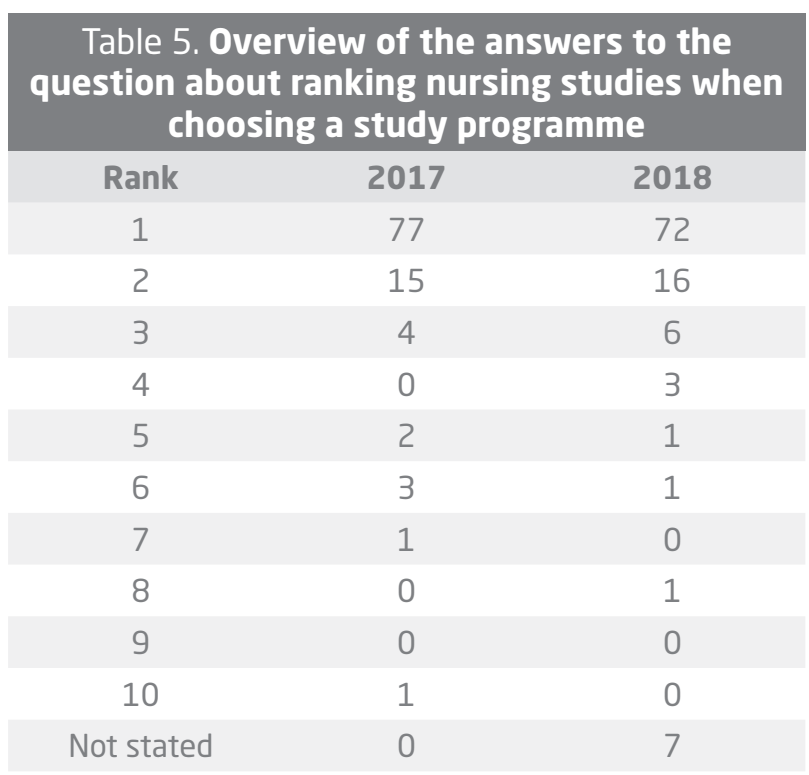

When analyzing data related to the questions whether a family member or a friend works in the health care system or whether they are a health care worker, the chi-square test was applied.

\begin{tabular}{|c|c|ccc|}
\hline \multicolumn{3}{c|}{$\begin{array}{c}\text { Table 6. Overview of the answers to the } \\
\text { question "Does a family member or a friend } \\
\text { work in healthcare?" }\end{array}$} \\
$\begin{array}{c}\text { works } \\
\text { in the } \\
\text { health } \\
\text { care } \\
\text { system }\end{array}$ & $\begin{array}{c}\text { nursing } \\
\text { high } \\
\text { school }\end{array}$ & $\begin{array}{c}\text { other } \\
\text { high } \\
\text { schools }\end{array}$ & $\begin{array}{c}\text { nursing } \\
\text { high } \\
\text { school }\end{array}$ & $\begin{array}{c}\text { other } \\
\text { high } \\
\text { schools }\end{array}$ \\
\hline Yes & 42 & 11 & 27 & 21 \\
\hline No & 39 & 11 & 31 & 20 \\
\hline Total & 81 & 22 & 58 & 41 \\
\hline
\end{tabular}

There is no statistically significant difference in the variable "family member or friend working in health care" with respect to the type of school students graduated from, neither for students enrolled in $2017\left(\chi^{2}=0.024 ; d f=1 ; p=0.878\right)$, nor for students who enrolled in $2018\left(\chi^{2}=0.210 ; \mathrm{df}=1 ; p=0.647\right)$.

During the analysis of the whole sample (all participants, both years) it was found that there is no statistically significant difference in the variable "family member or friend working in health care" with respect to the type of school students graduated from $\left(\chi^{2}=0.023 ; \mathrm{df}=1 ; p=0.879\right)$. 
Further analysis of data on a sample of 2017 participants found that there was no statistically significant difference in the ratio of answers to the question "Does a family member or friend work in health care?" $\left(\chi^{2}=0.087 ; \mathrm{df}=1 ; p=0.768\right)$, and that in the sample of participants from 2018, there is no statistically significant difference in the ratio of answers to the question "Does a family member or friend work in health care?" $\left(\chi^{2}=0.040 ; \mathrm{df}=1 ; p=0.841\right)$. Also, when analyzing the answers of all participants, no statistically significant difference was found in the ratio of answers to the question "Does a family member or friend work in health care?" $\left(\chi^{2}=0.005\right.$; $\mathrm{df}=1 ; p=0.944$ ).

\begin{tabular}{|c|c|c|c|c|}
\hline \multicolumn{5}{|c|}{$\begin{array}{c}\text { Table } 7 . \text { Overview of the answer to the } \\
\text { question - Is a family member a health } \\
\text { worker? }\end{array}$} \\
\hline \multirow{2}{*}{$\begin{array}{l}\text { health } \\
\text { care } \\
\text { worker }\end{array}$} & \multicolumn{2}{|c|}{2017} & \multicolumn{2}{|c|}{2018} \\
\hline & $\begin{array}{l}\text { nursing } \\
\text { high } \\
\text { school }\end{array}$ & other & $\begin{array}{l}\text { nursing } \\
\text { high } \\
\text { school }\end{array}$ & $\begin{array}{l}\text { other } \\
\text { high } \\
\text { schools }\end{array}$ \\
\hline Yes & 23 & 6 & 16 & 12 \\
\hline No & 58 & 16 & 42 & 29 \\
\hline Total & 81 & 22 & 58 & 41 \\
\hline
\end{tabular}

There is no statistically significant difference in the variable "family member is a health worker" with regard to the type of school the students graduated from, neither in the group of participants who enrolled in $2017\left(\chi^{2}=0.011 ; \mathrm{df}=1 ; p=0.917\right)$, nor in the group of participants who enrolled in the study in $2018\left(\chi^{2}=0.034 ; \mathrm{df}=1 ; p=0.855\right)$.

During the analysis of the whole sample (all participants, both years) it was found that there is no statistically significant difference in the variable "family member is a health worker" with regard to the type of school students come from $\left(\chi^{2}=0.006 ; d f=1\right.$; $p=0.940$ ).

Further analyses of data on a sample of participants from 2017 found that statistically significantly more students than expected answered "No" to the question "Is a family member a health worker" $\left(\chi^{2}=19660\right.$; $\mathrm{df}=1 ; \mathrm{p}=0.000)$. Also, in the sample of participants from 2018, statistically significantly more students than expected gave the answer "No" to the question "Is a family member a health worker" $\left(\chi^{2}=19360\right.$; $\mathrm{df}=1 ; p=0.000)$. When analyzing the answers of all participants included in the research, statistically significantly more students than expected gave the answer "No" to the question "Is a family member a health worker" $\left(\chi^{2}=39020 ; \mathrm{df}=1 ; p=0.000\right)$.

\section{Discussion}

Since the study of nursing is enrolled by students who have previously completed various types of high schools, and for some participants the study of nursing is a continuation of education in the nursing profession, we expected different answers to the question about the reasons for enrollment.

In both generations, students who previously completed nursing high school most often state the expansion of existing knowledge, the acquisition of new knowledge, and the continuation of previous education as the reasons for enrolling in nursing studies. In the 2017 generation, a larger number of participants stated that they like the job of a nurse (31\%) as a reason for enrolling in the study programme, compared to 2018, when they stated that they like being a nurse (15.8\%). Although the results are expected, we can say that they are important for the development of the profession and the planning of nursing staff because they speak of the desire for further professional development and some students state that they love or like the work they do. These students are familiar with the job of a nurse, they have decided to stay and develop professionally in the nursing profession, and it is to be expected that upon completion of their studies, they will be employed as nurses. As in most countries students enroll after graduating from other types of high schools since nursing education begins at the undergraduate level, data from other surveys can be compared with data obtained in this survey, and it refers to students who had previously completed other types of high school education.

Most of the participants who had previously graduated from other types of high schools most often state the following reasons for enrollment: interest in medicine, nursing, health, nursing is interesting to them, helping others and good employment opportunities. Participants of this research, as well as par- 
ticipants in other studies, single out altruistic $(7,8$, $9,10,11,12,14)$ and economic reasons such as job security $(10,9,11,14,15,16)$. In addition, they state that nursing is interesting to them. Analyzing the literature, we can see that the reasons for enrolling in the study of nursing have not changed significantly in the last twenty years. The desire to help and job security still dominate.

Participants in this study did not state, i.e. stated in small numbers, the diversity of work placements and the dynamics of nursing. Given the current shortage of nurses, it is important at all levels of education and enrollment in educational programmes to present the nursing profession as realistically as possible, but also show the dynamism and diversity of the nursing profession, the possibility of advancement with generally known information about the profession (helping other people, working with the ill, working with people) in order to encourage students to enroll in the study. The literature states positive influence of family members or friends on the choice of studies (profession) as well as previous positive experiences with nurses $(9,11,16,17)$, with special emphasis on the influence of a mother or a grandmother (15). In the survey, participants answered the question of whether a family member or friend works in health care. Slightly more participants answered "Yes" in the survey conducted in 2017 (51.4\% of participants), while in the sample of participants from 2018, slightly more participants answered "No" (51.5\%). By analyzing the results, we did not find statistically significant differences between individual groups of participants or in the entire sample.

Participants also answered the question "Is any of the family members a health worker?". In both samples, the majority of participants had given the answer "No" (71.8\% in 2017, and 71.7\% in 2018). The analysis of the results did not reveal a statistically significant difference with regard to the type of school from which the students come, neither for 2017 nor for 2018. Further processing of the data in the sample from 2017 and 2018 found that statistically significantly more students than expected answered "No" to the question whether a family member is a health worker. Also when analyzing the answers of all participants involved in the research, statistically significantly more students than expected answered "No".

In the results related to the question whether a family member or a friend works in health care and whether a family member is a health worker, the results of the participants in this research differ from the results of the participants in other research. The answers to the question about the reasons for enrollment also did not indicate a large number of answers related to the influence of family or friends. This question could be asked in future research and over several generations of students to determine whether the results relate only to these two generations of students or they can be generalized. Also, in the research that would be conducted on nurses, the question could be asked whether they would recommend their profession to their children and to provide an explanation of their answer. Namely, the job of a nurse is stated to be very demanding and difficult, and it is possible that nurses do not recommend this profession to their children and family members.

When choosing their studies, most students' first choice was the study of nursing at the higher education institution where this research was conducted. In the 2017 sample, the study of nursing was the first choice for 77 (74.7\%) participants, and in 2018 for $72(67.3 \%)$ participants. The study of nursing was the first or second choice for more than $80 \%$ of participants $(89.3 \%$ and $82.2 \%$ of participants, respectively). These data indicate that the study of nursing is the desired study for most students and it is to be expected that they are motivated to study but also to be a nursing professional.

The main limitation of the research is related to the place of research because the research was conducted at only one higher education institution for which there is the greatest interest enrollment in Croatia, and part of the results may be related to the fact that students were highly motivated to enroll in the study and acquire knowledge and skills from nursing practice. The research should be conducted on multiple nursing studies, over several generations to gain a more detailed insight into the reasons for enrolling in the study.

\section{Conclusion}

This research sought to determine the reasons for student enrollment in nursing studies. It was found that the results obtained between the two groups of 
participants differed - students who had previously completed high school for nurses and students who had previously completed other types of high school, which was expected. Students who had previously completed high school for nurses as reasons for enrollment in nursing studies most often state the expansion of existing knowledge, acquisition of new knowledge and continuation of previous education, and students who have completed other types of high school state interest in medicine, nursing, health, they find nursing interesting, helping others and good employment opportunities. The results of students who had completed other types of high schools are consistent with the results of other research. Other research state the fact of a family member or friend working in health care system or them being a health care worker as a positive factor for student enrollment. Participants in this research significantly more often state that family members do not work in the health care system. It was also found that the study of nursing at the higher education institution where the research was conducted was usually the first or second choice of students, which means that students in the choice of enrollment in nursing studies gave priority to the higher education institution where the research was conducted.

Information on the reasons for enrollment can help in planning the promotion of studies and the nursing profession in public to encourage students to enroll. A realistic portrayal of the profession is important in order to prevent the creation of an idealized image of the profession and the subsequent dropping out of studies or leaving the profession after graduation.

\section{References}

1. WHO. State of the world's nursing: investing in education, jobs and leadership. Geneva: World Health Organization; 2020.

2. OECD/EU. Health at a Glance: Europe 2018: State of Health in the EU Cycle. Paris: OECD Publishing; 2018. Available from: https://doi.org/10.1787/health_glance_eur-2018-en

3. Mulholland J, Anionwu EN, Atkins R, Tappern M, Franks PJ. Diversity, attrition and transition into nursing. J Adv Nurs. 2008;64(1):49-59.
4. Urwin S, Stanley R, Jones M, Gallagher A, Wainwright $P$, Perkins $A$. Understanding student nurse attrition: learning from the literature. Nurse Educ Today. 2010;30(2):202-7.

5. Dante A, Valoppi G, Saiani L, Palese A. Factors associated with nursing students' academic success or failure: a retrospective Italian multicenter study. Nurse Educ Today. 2011;31(1):59-64.

6. Salamonson $Y$, Everett $B$, Cooper $M$, Lombardo L, Weaver R, Davidson PM. Nursing as first choice predicts nursing program completion. Nurse Educ Today. 2014;34(1):127-31.

7. Hemsley-Brown J, Foskett NH. Career desirability: young people's perceptions of nursing as a career. J Adv Nurs. 1999;29(6):1342-50.

8. Boughn S, Lentini A. Why do women choose nursing? J Nurs Educ. 1999;38(4):156-61.

9. Larsen PD, McGill JS, Palmer SJ. Factors influencing career decisions: perspectives of nursing students in three types of programs. J Nurs Educ. 2003;42(4):168-73.

10. Dal U, Arifoglu BC, Razi GS. What factors influence students in their choice of nursing in North Cyprus? Procedia Soc Behav Sci. 2009;1:1924-30.

11. Mooney M, Glacken M, O'Brien F. Choosing nursing as a career: a qualitative study. Nurse Educ Today. 2008;28(3):385-92.

12. Miers ME, Rickaby CE, Pollard KC. Career choices in health care: is nursing a special case? A content analysis of survey data. Int J Nurs Stud. 2007;44(7):1196-209.

13. Wells JS, Norman IJ. The 'greying' of Europe - reflections on the state of nursing and nurse education in Europe. Nurse Educ Today. 2009;29(8):811-5.

14. Wilkes $L$, Cowin $L$, Johnson $M$. The reasons students choose to undertake a nursing degree. Collegian. 2015;22(3):259-65.

15. Glerean N, Hupli M, Talman K, Haavisto E. Young peoples' perceptions of the nursing profession: An integrative review. Nurse Educ Today. 2017;57:95-102.

16. McNally S, Azzopardi T, Hatcher D, O'Reilly R, Keedle H. Student perceptions, experiences and support within their current Bachelor of Nursing. Nurse Educ Today. 2019;76:56-61.

17. Price SL. Becoming a nurse: a meta-study of early professional socialization and career choice in nursing. J Adv Nurs. 2009;65(1):11-9.

18. Buerhaus PI, Donelan K, Norman L, Dittus R. Nursing students' perceptions of a career in nursing and impact of a national campaign designed to attract people into the nursing profession. J Prof Nurs. 2005;21(2):75-83.

19. Day RA, Field PA, Campbell IE, Reutter L. Students' evolving beliefs about nursing: from entry to graduation in a four-year baccalaureate programme. 1995 Nurse Educ Today. 2005;25(8):636-43.

20. Cowin LS, Johnson M. Many paths lead to nursing: factors influencing students' perceptions of nursing. Int Nurs Rev. 2011;58(4):413-9. 


\section{RAZLOZI UPISA STUDENATA NA STUDIJ SESTRINSTVA}

\section{Sažetak}

Cilj istraživanja bio je utvrditi razloge upisa studenata na studij sestrinstva, prioritete u izboru studija te razlike u razlozima i prioritetima izbora upisa na studij s obzirom na prethodno završenu srednju školu. Istraživanje je provedeno na studentima redovnog studija sestrinstva Zdravstvenog veleučilišta koji su upisali prvu godinu studija u akademskim godinama 2017./2018. i 2018./2019. U svrhu istraživanja primijenjen je anonimni upitnik koji obuhvaća pitanja koja se odnose na demografske podatke i pitanja koja se odnose na razloge povezane s upisom na studij sestrinstva, radi li netko od članova njihove obitelji ili prijatelja u sustavu zdravstva te je li netko od članova njihove obitelji zdravstveni radnik. Studenti su morali navesti na kojem se mjestu odabira na skali od 1 do 10 nalazio studij sestrinstva prilikom upisa na visoka učilišta. Studenti koji su prethodno završili srednju školu za medicinske sestre kao razloge za upis na studij sestrinstva najčešće navode proširivanje postojećih znanja, stjecanje novih znanja i nastavak prethodnog obrazovanja. Studenti koji su završili druge srednje škole kao razloge za upis navode interes za medicinu, sestrinstvo, zdravstvo, pomaganje drugima, dobre mogućnosti zapošljavanja i to da im je sestrinstvo zanimljivo. Ispitanici u ovom istraživanju znatno češće navode da članovi obitelji ne rade u zdravstvu. Prilikom upisa na studij većina studenata na prvom je mjestu navela studij sestrinstva pri visokoškolskoj ustanovi na kojoj je provedeno istraživanje, u uzorku 2017. 74,7 \% ispitanika, a 2018. $67,3 \%$ ispitanika. Nema statistički značajne razlike u prosječnom rangu odabira studija sestrinstva s ob- zirom na godinu upisa studija ( $p=0,692)$. Podaci o razlozima upisa na studij mogu pomoći pri planiranju promocije studija i sestrinske profesije u javnosti kako bi potaknuli studente na upis.

Ključne riječi: sestrinstvo, obrazovanje, razlozi upisa na studij 